\title{
A NEW INEQUALITY FOR A POINT IN THE PLANE OF A TRIANGLE
}

\section{JIAN LIU}

Abstract. In this paper, a new geometric inequality for a point in the plane of a triangle is proved by using mathematical software Maple. Also, a general inequality with one parameter and other three similar interesting inequalities checked by the computer are put forward as conjectures.

Mathematics subject classification (2010): 51M16, 51N20.

Keywords and phrases: triangle, point, difference substitution, conjecture.

\section{REFERENCES}

[1] O. Bottema, R. Ž. Djordjević, R. R. Janić, D. S. Mitrinović, And P. M. Vasić, Geometric Inequalities, Groningen, 1969.

[2] J. LiU, A weighted inequality involving the sides of a triangle, Creative Math. Inf. 19, 2 (2010), 160168.

[3] J. LiU, Some new inequality for an interior point of a triangle, J. Math. Inequal. 6, 2 (2012), 195-204.

[4] J. LIU, A geometric inequality with one parameter for a point in the plane of a triangle, J. Math. Inequal. 8, 1 (2014), 91-97.

[5] J. LIU, Two inequalities for a point in the plane of a triangle, Int. J. Geometry. 2, 2 (2013), 68-82.

[6] D. S. Mitrinović, J. E. PeČArić And V. Volenec, Recent Advances in Geometric Inequalities, Kluwer Academic Publishers, Dordrecht-Boston-London, 1989.

[7] Y.-D. WU, Z.-H ZHANG, AND Y.-R. ZANGP, Proving inequalities in acute triangle with difference substituion, J. Inequal. Pure and Appl. Math. 8, 3 (2007), Art. 81.

[8] W.-L. WANG, Approaches to Prove Inequalities, Harbin Institute of Technology Press, Harbin (2011) (in Chinese).

[9] L. YANG, Difference substitution and automated inequality proving, J. Guangzhou Univ. (Natural Sciences Edition), 5 (2) (2006), 1-7 (in Chinese).

[10] L. YANG, X.-R. HOU AND Z.-B. ZENG, A complete discrimination system for polynomials, Sci. China E, 1996, 39 (6):628-646.

[11] L. YANG, Solving harder problems with lesser mathematics, Proceedings of the 10th Asian Technology Conference in Mathematics, December 12-16, 2005, Cheong-Ju, South Korea.

[12] L. YANG AND B.-C. XIA, Automated Proving and Discoverering on Inequalities, Science Press, Beijing (2008) (in Chinese). 